\title{
Article
}

\section{Microphase-Separated Structure and Dynamic Viscoelastic Properties of Polyurethanes Elastomers Prepared at Various Temperatures and Cross-Linking Agent Contents}

\author{
Ken KoJIO ${ }^{\dagger}$, Shun Matsumura, Takuya Komatsu, Shuhei NozaKi, \\ Suguru Motokucho, Mutsuhisa FuruKaWA, and Kohji YoshinagA \\ Chemistry and Materials Science Division \\ Graduate School of Engineering, Nagasaki University, Japan \\ 1-14 Bunkyo-machi, Nagasaki 852-8521
}

\begin{abstract}
The relationship between a microphase-separated structure and dynamic viscoelastic properties of polyurethane elastomers (PUEs) prepared at various temperatures and cross-linking agent contents were investigated. The PUEs were synthesized with poly(oxytetramethylene) glycol (PTMG), 4,4'-diphenylmethane diisocyanate (MDI) and 1,4-butanediol (BD) and a mixture of BD and 1,1,1-trimethylol propane (TMP) by a prepolymer method. The PUEs are in the strong-segregation limit. The microphase-separated structure was investigated using Fourier-transform infrared spectroscopy (FT-IR), differential scanning calorimetry (DSC), small-angle x-ray scattering (SAXS) and atomic force microscope (AFM). The extent of microphase separation of the PUEs became stronger and weaker with increases in curing temperature and trifunctional TMP content, respectively. The consistent results obtained in this study would be quite helpful to design the desirable PUEs.
\end{abstract}

Key Words: Polyurethane elastomers / Microphase-separated structure / Dynamic viscoelastic properties /

Curing temperature / Cross-linking agent

\section{種々の硬化温度と架橋剤含有率で調製した ポリウレタンェラストマーのミクロ相分離構造と動的粘弾特性} 小椎尾 謙 ${ }^{\dagger}$, 松村 隼, 小松 拓也, 野崎 修平, 本九町 卓, 古川 睦久, 吉永 耕二

1. 緒言

ポリウレタン $(\mathrm{PU})$ は, 原料, 調製条件をはじめとする数 多くの条件を変化させることで，プラスチックにもゴムに もなり, 極めて多様な粘弾性挙動を示す，PUから弾性体を 得る場合，伸長を担うゴム状態の分子鎖をつなぎ止める部位 として, 化学架橋点あるいは物理架橋点のいずれも使用す ることができる。このことなどに起因して, PUエラストマー (PUE) の物性制御法は多数存在するが, それらの制御法が有 効である理由や原理には，いまだに不明な点が数多く残さ れている。 セグメント化ポリウレタンは, 屈曲なソフトセ グメントと剛直なハードセグメントからなり，各セグメン

長崎大学大学院工学研究科物質科学部門 干 852-8521 長崎市文教町 1-14

* Author to whom correspondence should be addressed.

Tel\&Fax: +81-95-819-2652, Email: kojio@nagasaki-u.ac.jp
トがリッチ相を形成することで，ハードセグメントドメイ ンが架橋部位として機能し, 弾性をはじめとして多彩な力 学物性を発現する。 スフィア構造, シリンダー構造などの ミクロ相分離構造は, 熱物性, 力学物性さらには電気物性, 光学物性などともかかわりがあり，物性を制御する上でミ クロ相分離構造を精密に制御することは必要不可欠である.

ポリウレタンのミクロ相分離状態の評価は, フーリエ変 換赤外分光 (FT-IR $)^{1-3)}$ ，示差走査熱量 (DSC) 測定 ${ }^{4,5}$, 小角 $\mathrm{X}$ 線散乱 $(\mathrm{SAXS})^{6,7)}$, 透過型電子顕微鏡 $(\mathrm{TEM})^{8)}$ および原子間 力顕微鏡 $(\mathrm{AFM})^{9-13)}$ などに基づき研究が行われてきた，FT-IR 測定ではハードセグメントおよびソフトセグメントの水素 結合状態や結晶状態から, DSC 測定では, ソフトセグメン トのガラス転移温度やハードセグメントの融点などから相 分離状態を推定することが可能である。また，SAXS 測定か らは，ミクロ相分離構造の形状，サイズや間隔とともに相 分離度に関する知見が得られる。さらに，TEM や AFM 観 察では, ミクロ相分離構造の局所構造を得ることが可能で 
ある. ${ }^{8-13)}$ 一方，動的粘弾性測定や誘電緩和測定などのレオロ ジー的な測定は, ミクロ相分離構造に関する知見とともに力 学物性などを与えることから以前から有用な手法として広 く用いられている. ${ }^{4,14,15)}$ 近年においても，ソフトセグメント に架橋を有するPUEの構造発展の評価 ${ }^{16}$, 長期間水につけ ておいたPUE 試料の分子量及び力学物性変化の評価 ${ }^{17)}$, 誘 電緩和測定に基づいた伸長過程におけるソフトセグメント の分子運動特性の評価 ${ }^{18)}$, さらには, 核磁気共鳴 (NMR) 測 定による水の含有挙動と高分子鎖と水分子の運動性評価 ${ }^{19}$ など引き続き研究が精力的に行われており, ポリウレタン の構造の全貌の解明とさらなる物性の向上のための基礎研 究の進展が今なお求められている.

本研究では, 硬化温度および架橋剂を種々変化させて系 統的に調製した相分離系 PUEについて, ミクロ相分離構造 と動的粘弾特性の関係を解明することを目的とする。

\section{2. 実験}

\section{1 試料の合成}

評価試料として，プレポリマー法により 12 種類の PUEを 調製した. Fig. 1 は，本研究で合成したPUEの反応式であ る。まず，乾燥したポリ（オキシテトラメチレン）グリコー ル $\left(\mathrm{PTMG}\right.$, 数平均分子量 $\left.\left(M_{\mathrm{n}}\right)=2000\right)$ および 4,4 ' - ジフェニ ルメタンジイソシアネート (MDI) を配合比 $K=[\mathrm{NCO}] /[\mathrm{OH}]$ $=3.3,80^{\circ} \mathrm{C}$ の条件で擋汼することでプレポリマーを合成し た，得られたプレポリマーに，硬化剤として，1,4-ブタンジ オール $(\mathrm{BD})$ あるいは $\mathrm{BD}$ と 1,1,1-トリメチロールプロパン $(\mathrm{TMP})$ の混合物を $\mathrm{NCO}$ INDEX $=[\mathrm{NCO}]_{\mathrm{pre}} /[\mathrm{OH}]=1.02$ の条件 で加え, 攪拌後, 硬化反応を行い, PUEを調製した。 ここで, $[\mathrm{NCO}]_{\mathrm{pre}}$ は, プレポリマー中に存在する $\mathrm{NCO}$ 基の濃度である. 反応温度を 4 条件 $\left(80,100,120\right.$ および $\left.140{ }^{\circ} \mathrm{C}\right), \mathrm{BD} / \mathrm{TMP}$ の比を 3 条件 $(10 / 0,8 / 2$ および $5 / 5)$ 変化させ合計 12 種類 のPUEを調製した１0/0のPUEは，化学架橋を有さず，線 状の分子構造を, $8 / 2$ および $5 / 5$ は三官能の TMP を組み込ん でいるため, 網目状の分子構造を有し，5/5 が最も高い化学 架橋密度を有する。

\section{2 膨潤試験}

非極性溶媒としてトルエンを, 極性溶媒として $N, N$ - ジメ チルアセトアミド (DMAc) を用い, $60{ }^{\circ} \mathrm{C}$ の恒温槽中で膨潤 させた。試料が平衡膨潤に達した後, 減圧乾燥炉中で恒量 になるまで乾燥させて，膨潤前および乾燥後の重量（それ ぞれ $W$ および $\left.W_{\mathrm{b}}\right)$ よりゲル分率 $g\left(=W_{\mathrm{b}} / W\right)$ を算出した。膨 潤度 $q$ は, $q=1+\left\{\left(W_{a}-W_{b}\right) / d_{\mathrm{s}} /\left(W_{b} / d_{p}\right)\right\}$ により求めた。 ここで, $W_{\mathrm{a}}, d_{\mathrm{s}}$ および $d_{\mathrm{p}}$ はそれぞれ平衡膨潤時の重量, 溶媒の密度, 試料の密度である。

\section{3 全反射フーリエ変換赤外分光 (ATR-FT-IR) スペクトル測定}

水素結合状態を評価するため, BIO RAD EXCALIBUR（Bio Rad Laboratories 製)を用いて, ATR 法により FT-IR 測定を行っ た。測定には MCT 検出器を用い, 測定条件は, 積算回数 32 回, 分解能 $2 \mathrm{~cm}^{-1}$ とした。

\section{4 示差走査熱量 (DSC) 測定}

熱的性質を評価するため, 理学電気(株)製 Thermo Plus ステー ションと示差走査型熱量計 (DSC8230) を用いて, DSC 測定 を行った。測定条件は，窒素ガス流量 $20 \mathrm{ml} / \mathrm{min}$, 昇温速度 $10^{\circ} \mathrm{C} / \mathrm{min}$ とした.

\section{5 小角 X 線散乱 (SAXS) 測定}

相分離状態およびサイズを評価するため，SAXS 測定を 行った. 測定は SPring-8 BL03XU(フロンティアソフトマター 開発産学連合ビームライン (FSBL)）において行った。 X 線 の波長 $0.1 \mathrm{~nm}$, カメラ長 $1.8 \mathrm{~m}$ の条件で, 検出器には CCD を用いた。

\section{6 原子間力顕微鏡 (AFM) 観察}

ミクロ相分離構造を直接観察するため, AFM 観察を行っ た。測定には SPA300HV および SPI4000（セイコーインスッ ルメンツ(株製）を用いた。インターミッテントモードを用い て, カンチレバーには, シリコン製, 短冊状, ばね定数 $13 \mathrm{~N} / \mathrm{m}$, 共振周波数 $126 \mathrm{~Hz}$ のものを用いた。

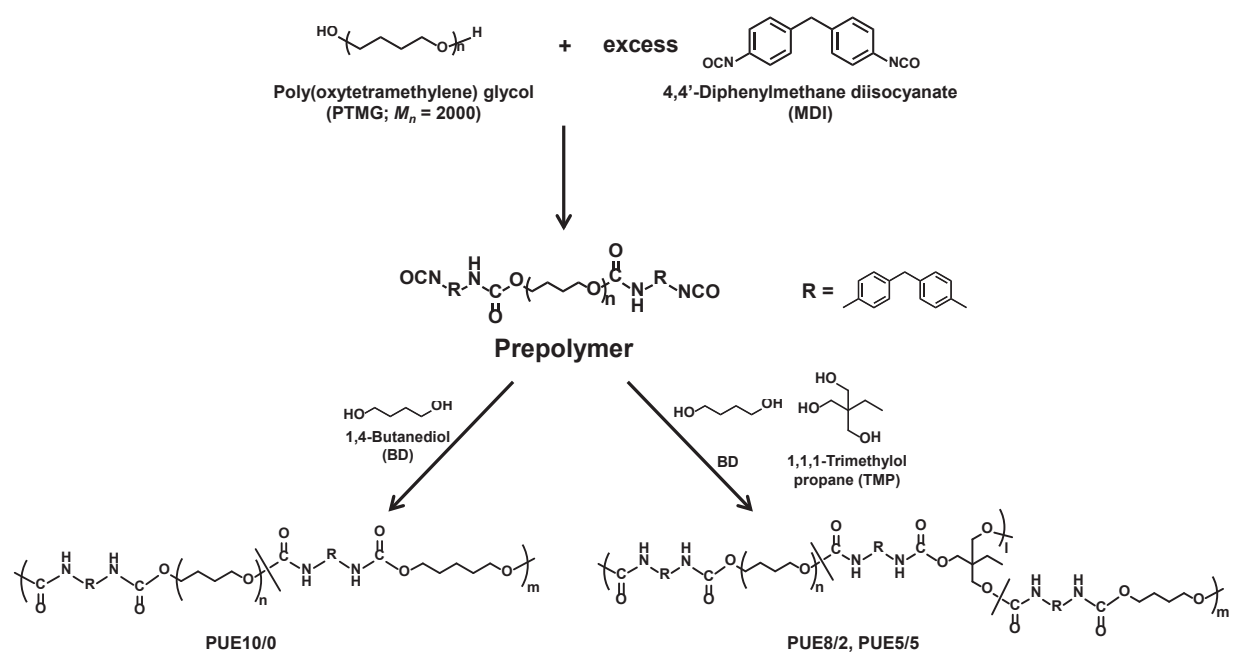

Fig. 1. Synthetic scheme of PUEs prepared in this study. 


\section{7 動的粘弾性測定}

セイコーインスツルメンツ(株)製熱分析レオロジーシステ ム (DMS6100) を用いて動的粘弾性測定を行った。測定条件 は, 昇温速度 $2.0^{\circ} \mathrm{C} / \mathrm{min}$, 温度範囲 $-140 \sim 250{ }^{\circ} \mathrm{C}$, 周波数 $10 \mathrm{~Hz}$ ，印加ひずみ $0.1 \%$ とした。

\section{3. 結果および考察}

\section{1 基礎物性評価}

試料名は, BD と TMPの重量比および硬化温度を用いて, PUE10/0-80のように表記した。 Table I は，各PUEのハー ドセグメント含有率，ゲル分率および膨潤度をまとめたも のである。非極性溶媒であるトルエンを用いた場合のゲル 分率は, すべての試料で $100 \%$ に近い值を示した。これよ り, 合成した試料は, 十分な分子量を有していることが確 認された。 また, ウレタン基間の水素結合を開裂できる極 性溶媒である DMAc を用いた場合のゲル分率は, PUE10/0 の場合, 完全に溶解して測定不可能であり, PUE8/2 およ びPUE5/5の場合， $100 \%$ に近い值であった。 これらのこ とより, PUE8/2 およびPUE5/5では, TMP が適切に組み 込まれて網目構造を形成していることが明らかである。一 方, 膨潤度はDMAc がトルエンよりも高い值を示した。 こ れは, DMAc はソフトセグメントのPTMGに侵入した上 ハードセグメントドメイン間の水素結合を開裂するのに対 し，トルエンでは PTMGへの侵入にとどまるためである. また, TMP 含有率で膨潤度を比較すると, トルエンの場合, PUE10/0 $\doteqdot \mathrm{PUE} 8 / 2>\mathrm{PUE} 5 / 5$, DMAc $の$ 場 合, PUE8/2> PUE5/5 であった. PUE5/5 が最も小さい值を示したのは, TMP 導入による化学架橋の影響が顕著に表れたことによる と考えられる.

\section{2 水素結合状態}

Fig. 2 は, BD/TMP 比が (a)10/0, (b)8/2 および (c)5/5 で種々 の硬化温度で調製したPUEの ATR-FT-IR スペクトルである. すべての試料において, 1730 および $1705 \mathrm{~cm}^{-1}$ 付近に, それ ぞれ遊離および水素結合したカルボニル伸縮振動 $\left(v(\mathrm{C}=\mathrm{O})_{\text {free }}\right.$ および $\left.v(\mathrm{C}=\mathrm{O})_{\mathrm{H}-\text { bond }}\right)$ が, 3290 および $3340 \mathrm{~cm}^{-1}$ 付近に, それ ぞれポリオールのエーテル酸素およびハードセグメント鎖の カルボニル酸素と水素結合した $\mathrm{NH}$ 基の伸縮振動 $\left(v(\mathrm{NH})_{\mathrm{HB} \text {-ether }}\right.$

Table I. Hard segment content, gel fraction and degree of swelling of polyurethane elastomers prepared in this study.

\begin{tabular}{|c|c|c|c|c|c|}
\hline \multirow[b]{2}{*}{ Sample } & \multirow{2}{*}{$\begin{array}{c}\text { HSC'1) } \\
{[\%]}\end{array}$} & \multicolumn{2}{|c|}{ Gel Fraction [\%] } & \multicolumn{2}{|c|}{ Degree of swelling } \\
\hline & & Toluene & $\mathrm{DMAc}^{21}$ & Toluene & DMAc ${ }^{2)}$ \\
\hline $\begin{array}{l}\text { PUE10/0-80 } \\
\text { PUE10/0-100 } \\
\text { PUE10/0-120 } \\
\text { PUE10/0-140 }\end{array}$ & $\begin{array}{l}33.5 \\
33.5 \\
33.4 \\
33.4\end{array}$ & $\begin{array}{c}100 \\
99 \\
99 \\
100\end{array}$ & $\begin{array}{l}\text { dissolved } \\
\text { dissolved } \\
22 \\
\text { dissolved }\end{array}$ & $\begin{array}{l}2.10 \\
2.13 \\
1.95 \\
2.02\end{array}$ & $\begin{array}{l}\text { dissolved } \\
\text { dissolved } \\
21.06 \\
\text { dissolved }\end{array}$ \\
\hline $\begin{array}{l}\text { PUE8/2-80 } \\
\text { PUE8/2-100 } \\
\text { PUE8/2-120 } \\
\text { PUE8/2-140 }\end{array}$ & $\begin{array}{l}33.5 \\
33.4 \\
33.4 \\
33.4\end{array}$ & $\begin{array}{l}100 \\
100 \\
100 \\
100\end{array}$ & $\begin{array}{l}96 \\
99 \\
98 \\
99\end{array}$ & $\begin{array}{l}2.05 \\
2.10 \\
2.22 \\
2.14\end{array}$ & $\begin{array}{l}4.14 \\
2.89 \\
4.10 \\
3.12\end{array}$ \\
\hline $\begin{array}{l}\text { PUE5/5-80 } \\
\text { PUE5/5-100 } \\
\text { PUE5/5-120 } \\
\text { PUE5/5-140 }\end{array}$ & $\begin{array}{l}33.4 \\
33.4 \\
33.4 \\
33.4\end{array}$ & $\begin{array}{l}97 \\
98 \\
98 \\
98\end{array}$ & $\begin{array}{l}98 \\
98 \\
98 \\
99\end{array}$ & $\begin{array}{l}1.96 \\
1.98 \\
1.96 \\
2.01\end{array}$ & $\begin{array}{l}2.40 \\
2.45 \\
2.37 \\
2.40\end{array}$ \\
\hline
\end{tabular}

$\begin{array}{ll}\text { 1) Hard Segment Content } & \text { 2) DMAc: } N, N \text {-Dimethylacetamide }\end{array}$
および $\left.v(\mathrm{NH})_{\mathrm{HB}-\text { carbonyl }}\right)$ が観測された。 各吸収バンドについて 波形分離を行った結果, 波数位置は硬化温度および TMP 含 有率に依存しなかったが，吸光度は大きく依存した， $v(\mathrm{C}=\mathrm{O})$ に関して, 硬化温度の上昇および TMP 含有率の増加に伴い,

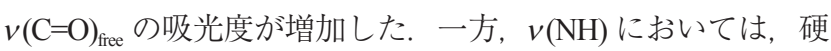
化温度の上昇および TMP 含有率の増加に伴い, $v(\mathrm{NH})_{\mathrm{HB} \text {-ether }}$ の 吸光度が増加した。 これらの傾向はよく対応した傾向である。
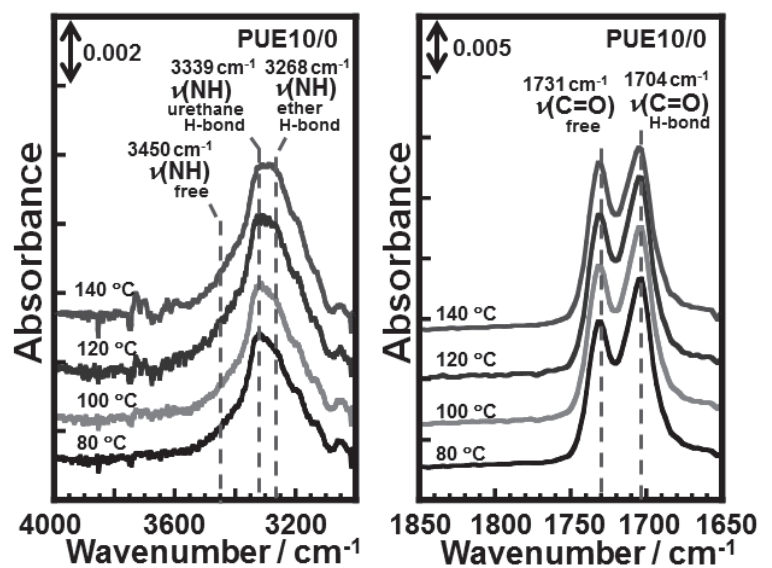

(a)
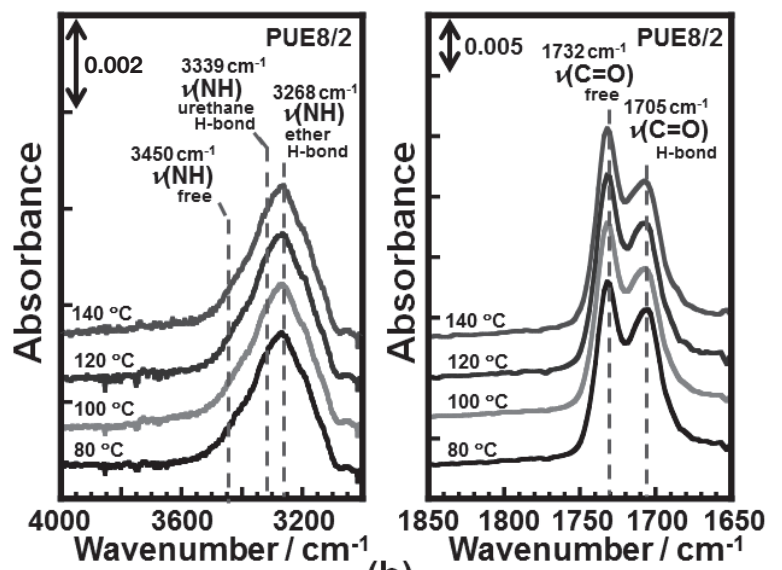

(b)
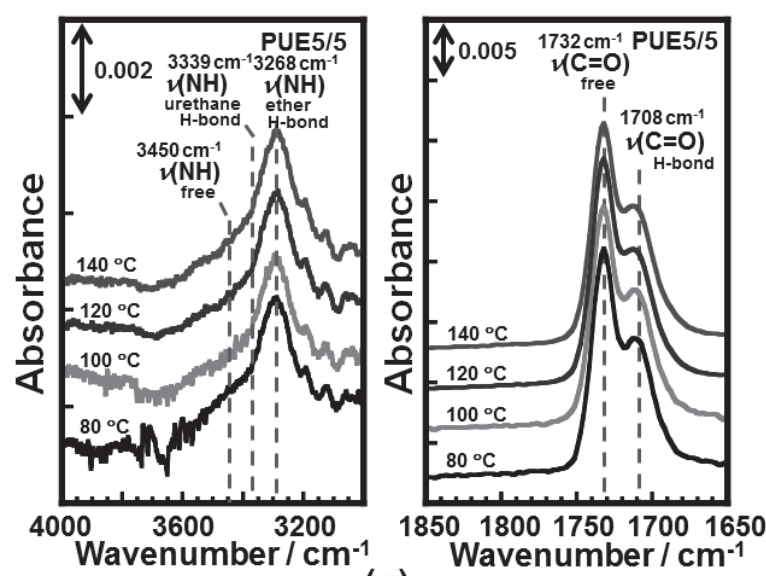

(c)

Fig. 2. Attenuated total reflection Fourier-transform infrared (ATR-FT-IR) spectra for the PUEs prepared at $80,100,120$ and $140{ }^{\circ} \mathrm{C}$ with $\mathrm{BD} / \mathrm{TMP}$ ratios of (a) $10 / 0$, (b) $8 / 2$ and (c) $5 / 5$. 
したがって，本研究で調製したPUEでは，ハードセグメ ントは自身同士で水素結合しているものとソフトセグメン 卜相に分散してエーテル酸素と水素結合を形成しているも のが混在しており, その割合は硬化温度の上昇および TMP 含有率の増加に伴い, ソフトセグメント相に存在するもの の割合が高くなることが明らかとなった。

\section{3 熱的性質}

Fig. 3 は, BD/TMP 比が (a)10/0, (b)8/2 おょよび (c)5/5で, 種々の硬化温度で調製したPUEの DSCサーモグラムである。 PUE 試料において, $-70 \sim-50{ }^{\circ} \mathrm{C}$ 付近にベースラインのシフ 卜， $0{ }^{\circ} \mathrm{C}$ および $160 \sim 200{ }^{\circ} \mathrm{C}$ 付近に吸熱ピークが観測された. これらは，それぞれソフトセグメント鎖のガラス転移温度 $\left(T_{\mathrm{g}}\right)$, 結晶化したソフトセグメント相の融点 $\left(T_{\mathrm{m}}, \mathrm{s}\right)$ およびハー ドセグメントの融点 $\left(T_{\mathrm{m}, \mathrm{H}}\right)$ に相当する. $T_{\mathrm{m}, \mathrm{S}}$ は, PUE10/0に おいてのみ観測された。 TMP 含有率および硬化温度の上昇 に伴い， $T_{\mathrm{g}}$ および $T_{\mathrm{m}, \mathrm{H}}$ は上昇した。 一般に，ブロック共重 合体における $T_{\mathrm{g}}$ の上昇あるいは低下は, 各セグメント間の 相互作用により誘起される分子鎖の拘束に由来する。本研究 で調製したポリウレタンの場合，ハードセグメント鎖の NH 基とソフトセグメント鎖のエーテル酸素との間の水素結合 形成に伴う分子鎖の拘束が存在し得る。したがって, TMP 含有率および硬化温度の上昇に伴う $T_{\mathrm{g}}$ の上昇は, ハードセ グメント鎖のソフトセグメント相への分散によると考えら れる，試料全体のミクロ相分離構造に関する考察は後述す る。一方, $T_{\mathrm{m}, \mathrm{H}}$ の上昇は, より純粋でサイズが大きい微結晶 が形成したことに相当する。ここで, MDI と BDの連鎖か らなるハードセグメント鎖からなる結晶ドメインの融点は, より平衡に近い状態で， $194^{20)}$ および $208{ }^{\circ} \mathrm{C}^{21)}$ であると報告 されている. したがって, 硬化温度の上昇に伴い, 熱力学 的により平衡に近い結晶を形成したことにより $T_{\mathrm{m}, \mathrm{H}}$ が上昇 したと考えられる，さらに，TMP含有率の増加に伴う $T_{\mathrm{m}, \mathrm{H}}$ の上昇は, -(MDI-BD) - 連鎖の $T_{\mathrm{m}}$ が MDI-BD の繰り返し単 位数 $n$ の変化 $(n=1 \sim 6)$ において, $n=3$ 付近で極大の融点を しめすという報告 ${ }^{22)}$ に基づくと, TMP を導入したことで, -(MDI-BD) - 連鎖が結晶化しやすい長さに適度に分断された ことによると推察される。

ATR-FT-IR 測定による水素結合状態と上述の DSC 測定の 熱的性質の結果より, 硬化温度の上昇に伴い, ソフトセグ メント相にハードセグメント鎖が存在する傾向が強くなる ものの, より発達したハードセグメント相を有するミクロ 相分離構造を形成すること, さらに, TMP 含有量の増加に 伴い, PUE8/2 では $T_{\mathrm{m}, \mathrm{H}}$ が上昇するという特異的な相分離の 進行はあるものの全体的には三次元架橋により相混合傾向 をもたらすことが明らかとなった。

\section{4 ミクロドメイン構造}

Fig. 4 は, PUE10/0-80 および PUE10/0-140の SAXS プロファ イルである。硬化温度が高い PUE10/0-140 の散乱ピークは, PUE10/0-80 のそれと比較して，散乱強度が高く，低角側に シフトし，ピーク幅は減少した. Invariantを計算した結果, PUE10/0-140 およびPUE10/0-80 の值はそれぞれ 0.25 および 0.21 であった。これらのことより，PUE10/0-140がミクロ相 分離傾向がより強いことが明らかとなった，ピーク位置よ り算出された PUE10/0-80, $-100,-120$ および -140 のドメイ
ン間距離は，それぞれ 15.6, 15.5, 19.8 および $21.7 \mathrm{~nm}$ であっ た． 3.3 で述べたように，MDI および BDからなるハードセ グメントの本来の結晶融解の融点は, $200{ }^{\circ} \mathrm{C}$ 以上であるため, 本研究で硬化した温度範囲で硬化温度が上昇すると, より 平衡状態に近いハードセグメントドメインを形成すると考 えられる。したがって，硬化温度の上昇に伴い微結晶のサ イズが増大したため，SAXS から得られたドメイン間距離が 増加したと考えられる。

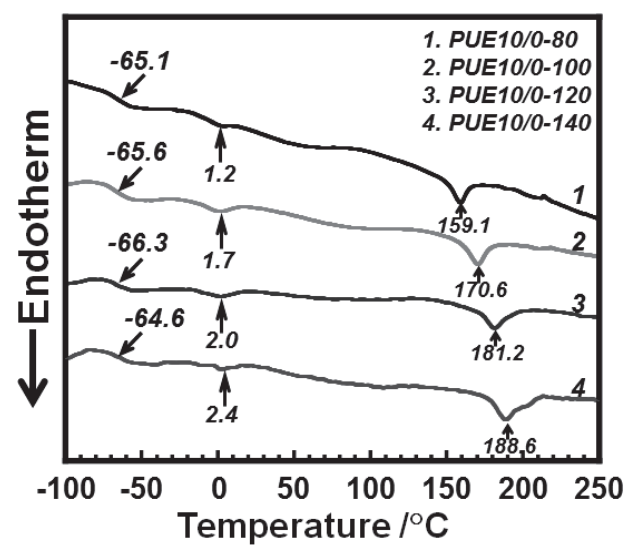

(a)

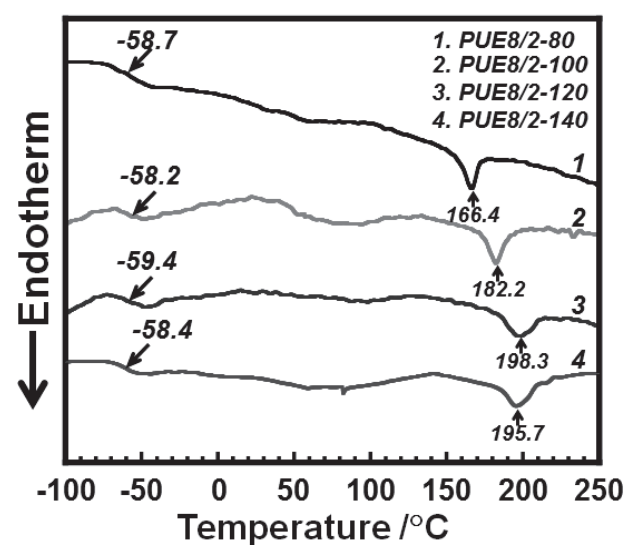

(b)

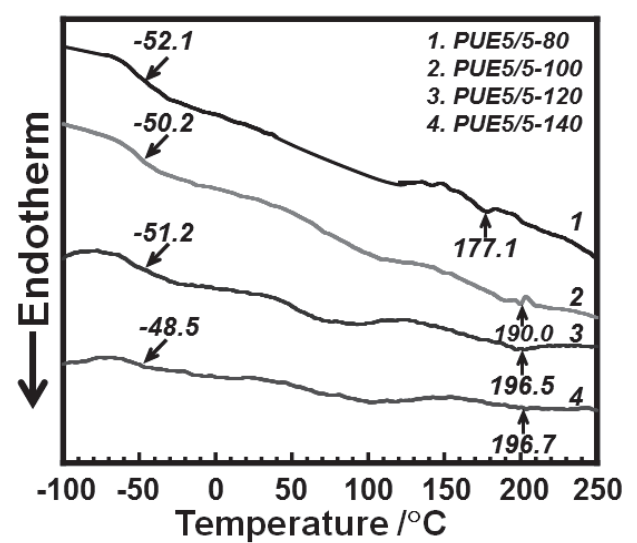

(c)

Fig. 3. Differential scanning calorimetry (DSC) curves for the PUEs prepared at $80,100,120$ and $140{ }^{\circ} \mathrm{C}$ with $\mathrm{BD} / \mathrm{TMP}$ ratios of (a) $10 / 0$, (b) $8 / 2$ and (c) $5 / 5$. 
Fig. 5 は, (a) PUE10/0-80 および (b) PUE10/0-140の AFM 位 相像である。像中明るい部分は, 位相差が大きい領域に相 当する.PUE10/0-80では, Fig. 5 (a)のように孤立したハード セグメントドメイン (暗い点) が数多く観察された。これに 対し, PUE10/0-140 では, Fig. 5 (a) に示すような構造に加えて, Fig. 5 (b) に示すような棒状のハードセグメントも併せて観察 された. さらに, この棒状ドメインの太さは, 孤立したハー ドセグメントドメインの大きさより顕著に増加した。 した がって, 硬化温度の上昇に伴う $T_{\mathrm{m}, \mathrm{H}}$ の上昇は, 棒状ドメイ ンの形成に由来すると考えられる。

\section{5 動的粘弾性測定}

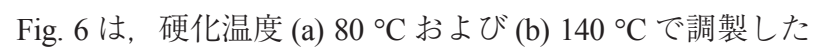
種々の TMP 含有率を有する PUE の動的貯蔵弾性率 $\left(E^{\prime}\right)$, 動 的損失弾性率 $\left(E^{\prime \prime}\right)$ および損失正接 $(\tan \delta)$ の温度依存性であ る. すべての PUE 試料において, $-140{ }^{\circ} \mathrm{C}$ 付近に, $E^{\prime} の$ 低下, $E^{\prime \prime お よ ひ ゙ ~} \tan \delta$ 曲線にピークが観測された。 これは, ソフト セグメント鎖のテトラメチレン鎖のクランクシャフト運動 に由来すると考えられる. ${ }^{23)}$ 次に, $-60 \sim-30{ }^{\circ} \mathrm{C}$ 付近に $E^{\prime}$ の急 激な減少および $\tan \delta$ のピークが観測された。 これは, ソフ トセグメント鎖のガラス転移に由来する $\alpha$ 緩和に帰属され

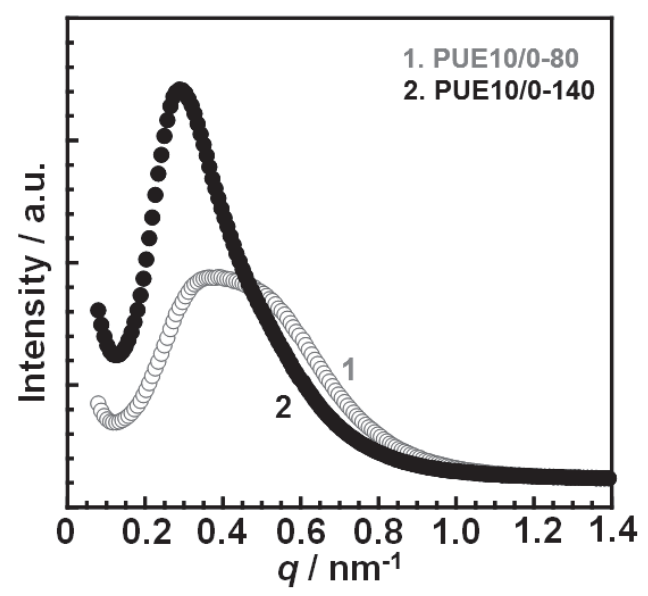

Fig. 4. Small-angle $x$-ray scattering profiles for the PUE10/0-80 and PUE10/0-140.

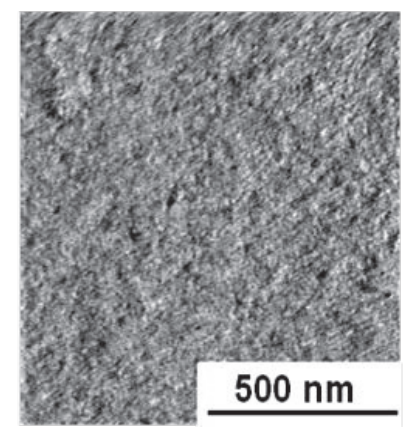

(a)

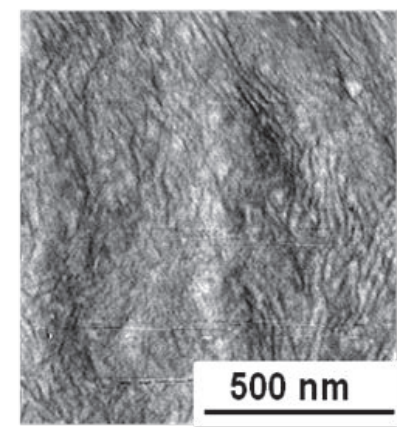

(b)
Fig. 5. AFM phase images for the (a) PUE10/0-80 and (b) PUE10/0-140.
る、化学架橋を導入する TMP 含有率の上昇に伴い, $\alpha$ 緩和 が観測される温度は上昇するとともに, $\tan \delta$ のピーク幅は 顕著に増大した，ATR-FT- IR 測定より，硬化温度あるいは TMP 含有率が高くなると, ハードセグメント鎖同士の水素 結合の割合が低下し，遊離のハードセグメント鎖の割合が 増加したこともあわせて考えると， $\alpha$ 緩和が観測される温度 の上昇と $\tan \delta$ のピーク幅の増大は, ソフトセグメント相へ ハードセグメント鎖が分散し, ソフトセグメント鎖のエーテ ル酸素とハードセグメント鎖の NH 基が水素結合を形成し, 様々な相互作用状態のソフトセグメントが存在したことで よく説明できる.

TMP を含まない PUE10/0の試料では，ガラス - ゴム転 移域からゴム状平坦領域に入る前の $-20{ }^{\circ} \mathrm{C}$ 付近において, $E^{\prime}$ 曲線に肩部が観測された。 これは，ガラス状態で分子運動 が凍結されていたソフトセグメント鎖が，ガラス - ゴム転移 域を経てミクロブラウン運動を開始した後, 再配列結晶化し たことに起因すると考えられる。 この $-20{ }^{\circ} \mathrm{C}$ 付近の肩部は, PUE8/2 およびPUE5/5 の試料では観測されなかった. このこ

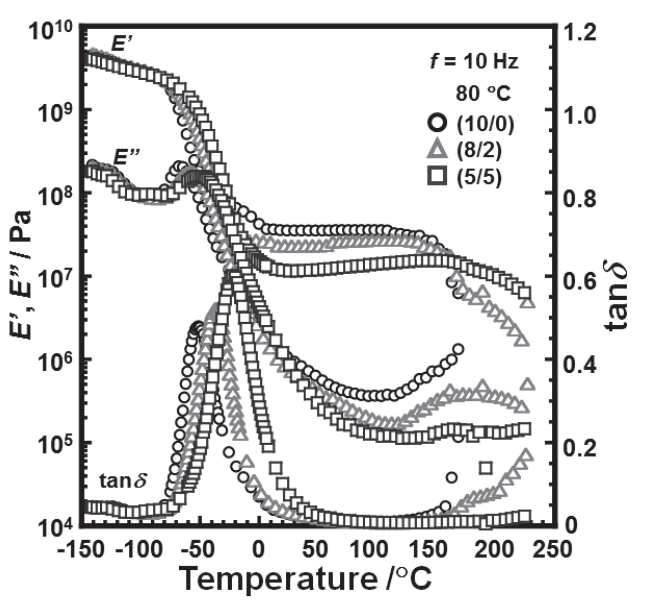

(a)

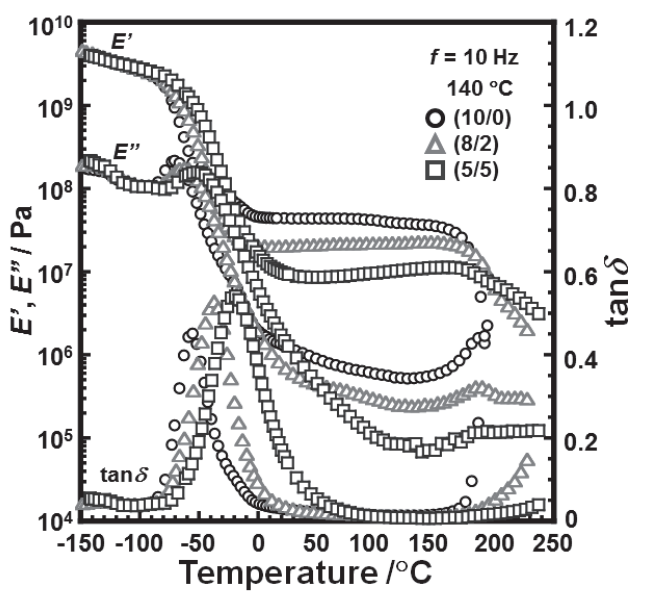

(b)

Fig. 6. Temperature dependence of storage modulus $\left(E^{\prime}\right)$, loss modulus $\left(E^{\prime \prime}\right)$ and loss tangent $(\tan \delta)$ for the PUEs prepared at (a) 80 and (b) $140{ }^{\circ} \mathrm{C}$ with $\mathrm{BD} / \mathrm{TMP}$ ratios of $10 / 0,8 / 2$ and $5 / 5$. 
とは, PUE8/2 および PUE5/5 が, PUE10/0よりも相分離傾向 が低く，ソフトセグメント相内に存在したハードセグメン 卜鎖により再配列結晶化が抑制されたためと考えられる.

ゴム状平坦域における各試料の $E^{\prime}$ 值は, TMP 含有率の増 加に伴い，低下した。これは，TMPの導入により，ハード セグメント鎖同士の水素結合の形成および結晶化が抑制さ れ，物理架橋部位として働くことが可能なハードセグメン トドメインの形成が抑制されたためと考えられる。すなわ ち, TMPの組み込みにより, 試料全体の化学架橋密度は増 加するものの, ハードセグメントドメインによる物理架橋 密度は低下したため， $E^{\prime}$ 值は低下したと考えられる。した がって, PUEにおける化学架橋と物理架橋は弾性率に関し てトレードオフの関係にあり, 物理架橋の方がゴム状平坦 域の $E^{\prime}$ 值には支配的に働くと言える。また， $0{ }^{\circ} \mathrm{C}$ 付近から $150{ }^{\circ} \mathrm{C}$ 付近のゴム状平坦領域の $E^{\prime}$ 值は, TMP 含有率が高い PUE5/5 で顕著に温度とともに上昇し, エントロピー弾性を 示した。 このことから, PUE5/5 は, ゴム状平坦域の $E^{\prime}$ 值の 上昇をもたらすハードセグメントドメイン（物理架橋部）は あまり形成されていないが, 化学架橋は十分に形成されてい ることが明らかである。ささらに高温域において，PUE10/0で は, $150{ }^{\circ} \mathrm{C}$ 付近で流動に伴う $E^{\prime}$ 值の著しい低下が観測され たのに対し，PUE5/5 ではわずかな $E^{\prime}$ 值の低下を示したもの の, 流動による顕著な $E^{\prime}$ 值の低下は観測されなかった。なお, PUE8/2 では, PUE10/0 と PUE5/5 の中間的な挙動が顕著に観 測された。すなわち, $170{ }^{\circ} \mathrm{C}$ 付近で, 結晶化したハードセ グメントの融解に伴う $E^{\prime}$ 值の低下が観測され, その後一旦 $E^{\prime}$ 值の低下の度合いが低下し, さらにその後 $E^{\prime}$ 值が顕著に 低下した。 $E^{\prime \prime}$ 曲線において，ハードセグメントドメインの 融解は, ピークとして観測された. 高温度での $E^{\prime}$ 值の低下 は, 試料の熱分解の可能性が考えられる. 以上の結果より, TMP を含有している試料では, ハードセグメントドメイン が融解した後, 化学架橋の存在により流動を軽減する傾向 を示し，最終的な流動に至ることが明らかとなった。

硬化温度の影響を評価するため, Fig. 7 に, BD/TMP 比が (a) $10 / 0$, (b) $8 / 2$ および (c) $5 / 5$ で, 種々の温度で調製した PUE

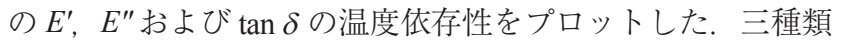
の TMP 含有率で調製したPUE の動的粘弾性の温度依存性へ の硬化温度の影響 (Fig. 7) は, TMP 含有率のそれ (Fig. 6) と 比較すると小さかった，硬化温度の上昇に伴い，PUE10/0で は $\alpha$ 緩和が観測される温度付近において，わずかな影響が 観測された。 ゴム状平坦域の $E^{\prime} の$ 值は, 硬化温度上昇に伴い, Fig. 7(a)の PUE10/0 では上昇したのに対し, PUE5/5 では低 下した. AFM 観察より明らかになったように, PUE10/0では, $80{ }^{\circ} \mathrm{C}$ で硬化するとスフィア構造を， $140{ }^{\circ} \mathrm{C}$ で硬化するとシ リンダー構造を形成する。したがって, 局所的には異方的 である $140{ }^{\circ} \mathrm{C}$ の方が, 等方的なスフィア構造を有する $80{ }^{\circ} \mathrm{C}$ より，ひずみのハードセグメントへの伝達が起こり易いと 考えられる。このため, ハードセグメントドメインの構造 形成が, 熱平衡に基づいて進行できるPUE10/0 では, 硬化 温度の上昇に伴い，ゴム状平坦域における $E^{\prime} の$ 值が上昇し たと考えられる。これに対し，PUE5/5では，硬化温度が上 昇した場合にも，発達したハードセグメントドメインは形 成されず，むしろ高温下では BD と TMP の反応がより均一 に進行することにより, ( MDI-BD -白の連鎖が形成されず, ハードセグメントドメインの形成が抑制されたため, ゴム
状平坦域における $E^{\prime}$ 值が低下したと考えられる.

さらに, PUE10/0 および PUE8/2では, $170{ }^{\circ} \mathrm{C}$ 付近に観測 された流動開始温度が, 硬化温度の上昇に伴い, 上昇した のに対し，PUE5/5 では，硬化温度に依存しなかった。この ことは, TMP 含有率が低ければ, この温度域でより熱平衡 状態に近いハードセグメントドメインを形成して，流動開 始の温度が上昇するが，TMP 含有率が高くなるとその傾向 を示すことができず, 流動開始温度はほぼ一定であったと 考えられる。

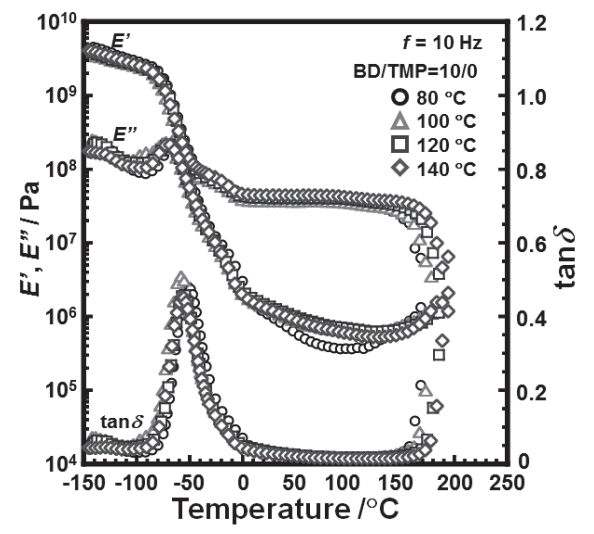

(a)

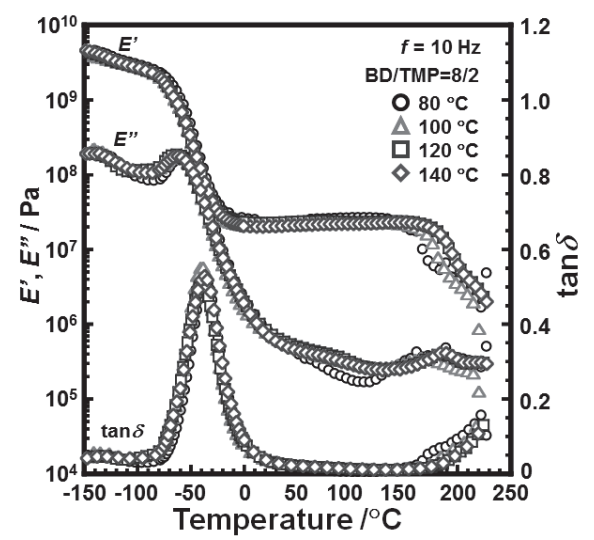

(b)

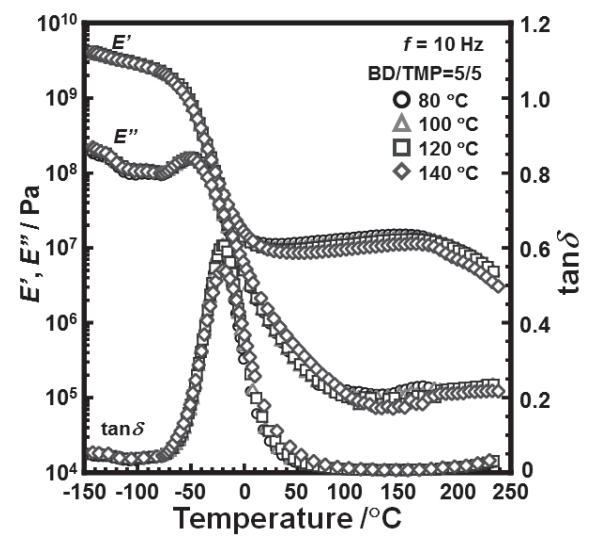

(c)

Fig. 7. $E^{\prime}, E^{\prime \prime}$ and $\tan \delta$ for the PUEs prepared at $80,100,120$ and $140{ }^{\circ} \mathrm{C}$ with BD/TMP ratios of (a) 10/0, (b) $8 / 2$ and (c) $5 / 5$. 


\section{4. 結 論}

種々の硬化温度および架橋剤含有率で相分離系 PUE を調 製しミクロ相分離構造と動的粘弾特性を評価した。硬化温度 の上昇に伴い, ソフトセグメント中に存在するハードセグ メント鎖の割合が上昇するものの，発達したハードセグメ ントドメインを形成し, ミクロ相分離傾向が強くなること が明らかとなった. 動的粘弾性測定の結果も, ミクロ相分 離構造と対応した結果を示し, 本研究で得られた知見に基 づき, 硬化温度および架橋剤含有量を調製することで要求 物性を満たす材料を調製するための重要な指針が得られた。

\section{謝辞}

SAXS 測定を行うにあたり，実験補助を賜りました公益財 団法人高輝度光科学研究センター (JASRI) の増永 啓康 博士 に感謝致します。

\section{REFERENCES}

1) Yokoyama T, Advances in Urethane Science and Technology, 6, 1 (1978).

2) Lee HS, Wang YK, Hsu SL, Macromolecules, 20, 2089 (1987).

3) Brunette CM, Hsu SL, MacKnight WJ, Macromolecules, 15, 71 (1982).

4) $\mathrm{Ng} \mathrm{NH}$, Allegrezza AE, Seymour RW, Cooper SL, Polymer, 14, 255 (1973).

5) Koberstein JT, Stein RS, J Polym Sci, Polym Phys, 21, 1439 (1983).

6) Furukawa M, Komiyama M, Yokoyama T, Angew Makro Chem, 240, 205 (1996).

7) Koberstein JT, Russell TP, Macromolecules, 19, 714 (1986).

8) Li C, Cooper SL, Polymer, 31, 3 (1990).
9) McLean RS, Sauer BB, Macromolecules, 30, 8314 (1997).

10) Garrett JT, Siedlecki CA, Runt J, Macromolecules, 34, 7066 (2001).

11) Kojio K, Uchiba Y, Mitsui Y, Furukawa M, Sasaki S, Masunaga H, Okuda H, Macromolecules, 40, 2625 (2007).

12) Kojio K, Uchiba Y, Kugumiya S, Nishino Y, Furukawa M, Polym J, 41, 118 (2009).

13) Kojio K, Uchiba Y, Yamamoto Y, Motokucho S, Furukawa M, J Phys Conf Ser, 184, 012028 (2009).

14) Kajiyama T, MacKnight WJ, Macromolecules, 2, 254 (1969).

15) North AM, Reid JC, Euro Polym J, 8, 1129 (1972).

16) Pichon PG, David L, Mechin F, Sautereau H, Macromolecules, 43, 1888 (2010).

17) Chaffin KA, Buckalew AJ, Schley JL, Chen X, Jolly M, Alkatout JA, Miller JP, Untereker DF, Hillmyer MA, Bates FS, Macromolecules, 45, 9110 (2012).

18) Lee HK, Fragiadakis D, Martin D, Milne A, Milne J, Runt J, Macromolecules, 43, 3125 (2010)

19) Zhu H, Huinink HP, Adan OCG, Kopinga K, Macromolecules, 46, 6124 (2013).

20) Saotome K, Komoto H, J Polym Sci, A-1: Polym Chem, 5, 119 (1967).

21) Chamberlin Y, Pascault JP, Letoffe M, Claudy P, J Polym Sci A, 20, 1445 (1982).

22) Hwang KKS, Wu G, Lin SB, Cooper SL, J Polym Sci: Polym Chem Ed, 22, 1677 (1984).

23) Ferry JD, "Viscoelastic Properties of Polymers", 3 rd ed. (1980), John Wiley \& Sons Inc, NY p 450. 